\title{
Working
}

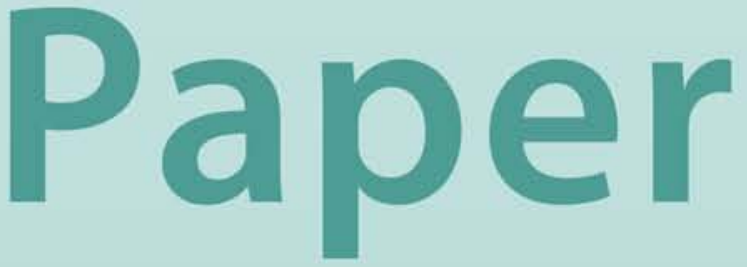


Official Intervention in the Foreign Exchange Market: Elements of Best Practice

\author{
Jorge Iván Canales-Kriljenko, Roberto
}

Guimarães, and Cem Karacadă̆ 


\title{
IMF Working Paper
}

\author{
Monetary and Financial Systems Department
}

\section{Official Intervention in the Foreign Exchange Market: Elements of Best Practice}

\author{
Prepared by Jorge Iván Canales-Kriljenko, Roberto Guimarães, and Cem Karacadağ ${ }^{1}$ \\ Authorized for distribution by Shogo Ishii
}

July 2003

\begin{tabular}{l} 
Abstract \\
$\begin{array}{l}\text { The views expressed in this Working Paper are those of the author(s) and do not necessarily } \\
\text { represent those of the IMF or IMF policy. Working Papers describe research in progress by the } \\
\text { author(s) and are published to elicit comments and to further debate. }\end{array}$ \\
\hline
\end{tabular}

This paper offers guidance on the operational aspects of official intervention in the foreign exchange market, particularly in developing countries with flexible exchange rate regimes. A brief survey of the literature and country experience is followed by an analysis of the objectives, timing, amount, degree of transparency, and choice of markets and counterparties in conducting intervention. The analysis highlights the difficulty of detecting exchange rate misalignments and disorderly markets, and argues in favor of parsimony in official intervention. Determining the timing and amount of intervention is a highly subjective exercise, and some degree of discretion is almost always necessary, though policy rules may serve as "rules of thumb."

JEL Classification Numbers: E58, F31, G28

Keywords: foreign exchange intervention, exchange rate policy

Authors' E-Mail_ jcanaleskriljenko@imf.org, rguimaraes@imf.org, Addresses: ckaracadag@imf.org

${ }^{1}$ The authors gratefully acknowledge Shogo Ishii's support and guidance for this project and Kai Barvell, Hervé Ferhani, Shyamala Gopinah, Masahiko Takeda, Barry Topf, and Mark Zelmer for their insights from a practitioner's perspective. We also thank participants in a Monetary and Financial Systems Department seminar for providing valuable comments. All errors are the authors' responsibility. 


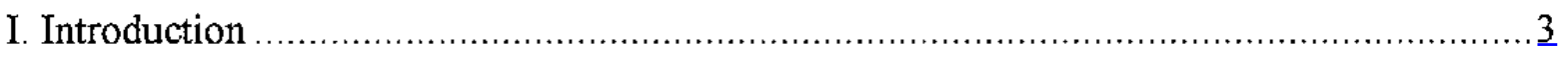

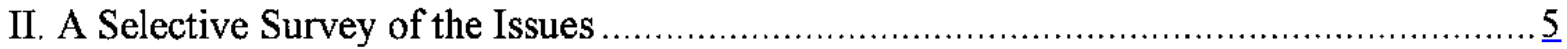

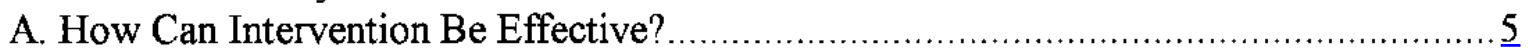

B. Trends and Experience in Foreign Exchange Intervention ................................

C. Key Lessons from the Literature and Selected Country Experience ....................... 12

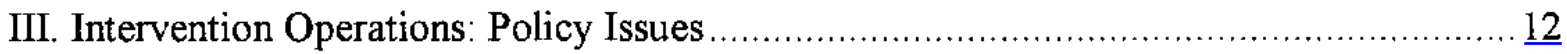

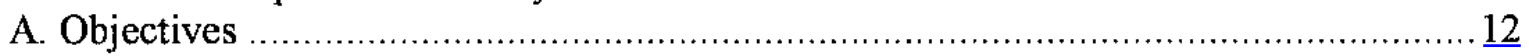

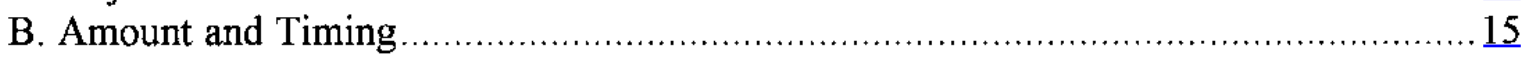

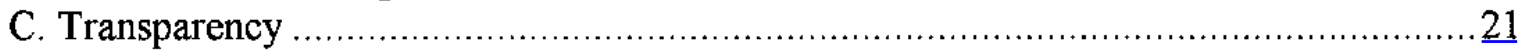

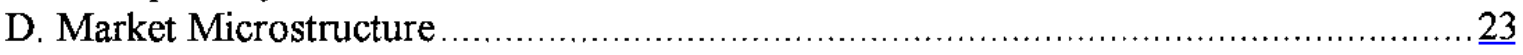

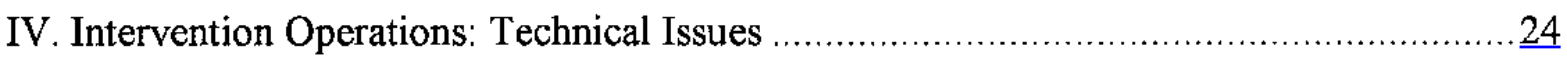

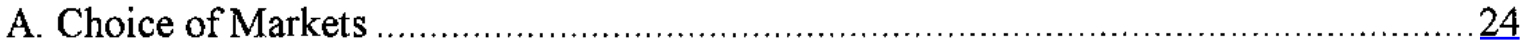

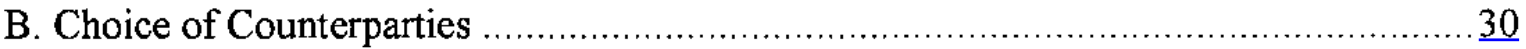

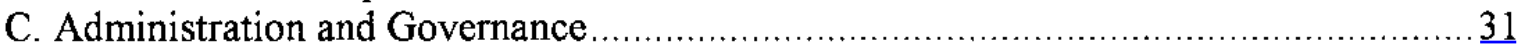

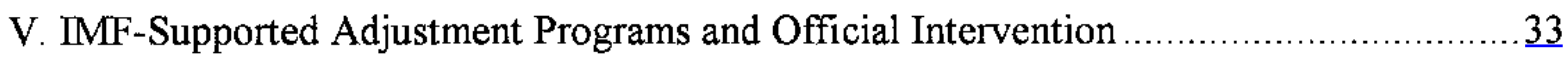

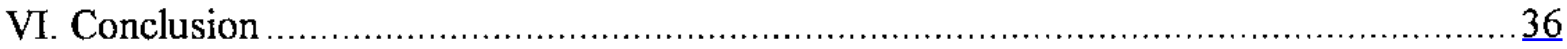

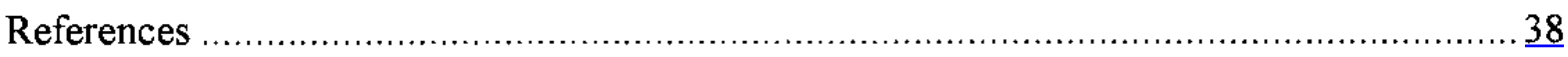

Figures

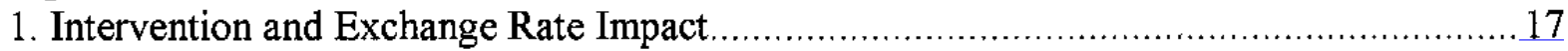

Boxes

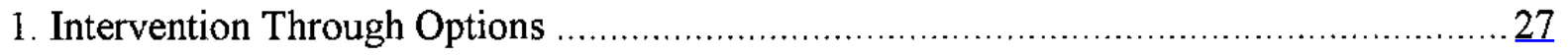

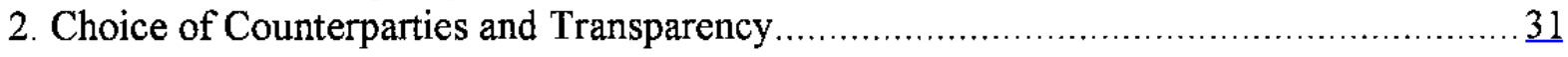




\section{INTRODUCTION}

Intervention in the foreign exchange market can be an important instrument for central banks, particularly in developing economies. However, it can put the central bank's credibility and scarce foreign exchange reserves at risk. Operational aspects of intervention, including the timing, frequency, amounts, and modalities of intervention, are among the most important decisions taken by monetary authorities. ${ }^{2}$ Yet, despite a vast literature on the effectiveness of intervention, few sources offer guidance on the operational issues and best practices in this area--a gap this study endeavors to fill.

This paper is devoted primarily to intervention under flexible exchange rate regimes. Under more rigid exchange rate arrangements, including various forms of pegs, central banks have little discretion over intervention policies. Official foreign currency sales and purchases automatically bridge the gap between supply and demand to ensure equilibrium at the predetermined exchange rate. The policy trade-offs and operational issues discussed here apply mainly to countries with independently floating or managed floating exchange rate regimes in which the monetary policy framework is not anchored by an exchange rate target.

In this paper, intervention is defined as official purchases and sales of foreign exchange to achieve one or more of the following four objectives: moderating exchange rate fluctuations and correcting misalignment; addressing disorderly market conditions; ${ }^{3}$ accumulating foreign exchange reserves; and supplying foreign exchange to the market. This definition is broader than the standard definition of intervention in the literature, which focuses exclusively on exchange rate-related objectives. ${ }^{4}$ The definition aims to capture what are known to be widely adopted policy objectives of foreign exchange operations in many developing and

\footnotetext{
${ }^{2}$ In some countries, the central government may be the responsible authority for intervention, but for convenience, this paper refers to the central bank as the agency in charge of conducting intervention operations.

${ }^{3}$ Disorderly market conditions are characterized by sharp fluctuations in the exchange rate, high exchange rate volatility, wide bid-offer spreads relative to tranquil periods, and sudden changes in foreign exchange market turnover and order flow. Addressing disorderly market conditions is among the principles that Fund members are encouraged to follow in the conduct of exchange rate policy. In particular, "A member should intervene in the exchange market if necessary to counter disorderly conditions, which may be characterized inter alia by disruptive short-term movements in the exchange value of its currency" (IMF, 2002).
}

${ }^{4}$ The standard definition and use of the term "intervention" in the literature have not always been consistent. Intervention has often been defined narrowly (as central bank foreign exchange operations targeting exchange rate movements) but also used more broadly (as including foreign exchange operations undertaken for purposes unrelated to those in the original definition - for example, portfolio rebalancing and reserve accumulation). 
transition countries (hereinafter collectively referred to as developing countries) to which the best practices advocated here are primarily intended to apply.

Our definition includes reserve accumulation and supplying foreign exchange because they are common objectives of intervention in many developing countries. Reserve accumulation is particularly important for countries intent on building investor confidence and strengthening their debt-repayment capacities and external liquidity positions. Where the public sector is a prime foreign exchange earner, such as in oil-producing countries, and the central bank is the foreign exchange agent of the public sector, central banks intervene mainly to supply foreign exchange to the economy at large. This also occurs in the few countries where some foreign exchange earners must surrender their foreign exchange receipts to the central bank.

Following the convention in the literature, the definition of intervention is narrowed to that which is sterilized. Sterilized intervention refers to central bank purchases and sales of foreign exchange that do not affect domestic monetary conditions (base money or short-term interest rates). ${ }^{5}$ To the extent that a foreign exchange operation is not, or is only partially, sterilized, then the component that is left "unsterilized" is equivalent to a monetary policy operation. $^{6}$

Across the range of intervention objectives and the policy frameworks under which they are pursued, central banks face the same set of questions on the mechanics of intervention. The main goal of this paper is to provide an overview of the policy, technical, and administrative questions that need to be solved to intervene in the foreign exchange market effectively, particularly in developing economies with flexible exchange rate regimes. Key issues that will be addressed include the following:

- Amount and timing. When and in what amounts should a central bank intervene in the foreign exchange market? Should official interventions be rules based or discretionary? What market factors (liquidity, order flow, etc.) should be used to help determine the timing and amount of intervention?

\footnotetext{
${ }^{5}$ Foreign exchange operations' impact on base money may be reversed (sterilized) - -for example, by an open market operation.

${ }^{6}$ It is also worth noting that, in practice, intervention in the foreign exchange market does not affect the money supply on the day of intervention, but rather on the day of settlement. Intervention is only one of many factors affecting base money, including movements in bank reserves and government financial operations; and its monetary effect is taken as a given when managing domestic liquidity. Intervention and monetary policy decisions and operations are thus independent of each other.
} 
- Degree of transparency (secret versus public). Should central bank interventions be announced or kept secret? What are the pros and cons of secrecy versus openness?

- $\quad$ Markets and counterparties. In which currency pair, instruments (spot or forward contracts), and trading locations (onshore or offshore) should intervention take place? With whom (any authorized dealer or primary dealers) should the central bank trade and how should it approach them (directly, through agents, or through brokers) to achieve its intervention objectives?

The remainder of the paper is organized as follows. Section II reviews the academic literature on the conditions under which intervention may be effective. Section III discusses the operational questions central banks face in deciding when and how to intervene, while Section IV is devoted to the more technical aspects of intervention. Section V discusses the implications of IMF-supported programs for intervention. Section VI concludes.

\section{A Selective Survey of The Issues}

This section reviews selected country experience and the academic literature to draw lessons on operational aspects of official intervention in the foreign exchange market.

\section{A. How Can Intervention Be Effective?}

Exchange rates are supposed to reflect basic supply and demand conditions, which in turn, ought to be linked to underlying macroeconomic fundamentals. The academic literature provides favorable evidence on the relationship between exchange rates and fundamentals in the long-term in economies with full capital mobility (Sarno and Taylor, 2002, Rogoff, 1996, and Chinn and Meredith, 2001). The parity conditions also hold in developing economies with partial capital mobility (Tanner, 1998).

However, exchange rates deviate substantially from values implied by fundamentals in the short term, even in well-functioning foreign exchange markets (Sarno and Taylor, 2002). Exchange rate movements violate the uncovered interest rate and purchasing power parity conditions and appear to be excessively volatile compared to underlying macroeconomic fundamentals (Mark, 2001). Moreover, macroeconomic models of exchange rate determination generally fail to outperform a naïve random walk model in out-of-sample forecasting at short time horizons (Rogoff, 1999).

The disconnect between short-term exchange rate levels and macroeconomic fundamentals creates a role for sterilized intervention. In particular, intervention may be used, possibly in conjunction with monetary policy, to stabilize market expectations, calm disorderly markets, and limit unwarranted exchange rate movements resulting from temporary shocks.

Intervention also may be used in conjunction with policies to redress macroeconomic imbalances. Intervention can complement efforts to place macroeconomic policies on a sustainable path by resisting disruptive changes in the exchange rate, but only if there is a credible commitment to, and tangible progress on, macroeconomic adjustment. 
Intervention is not an independent policy tool. Its effectiveness is conditional upon the consistency of targeted exchange rates with macroeconomic policies. Moreover, with high capital mobility, exchange rate and monetary policies cannot be conducted independently. Intervention is especially unlikely to be effective when adverse exchange movements reflect persistent macroeconomic imbalances. Protracted one-sided intervention on a large scale probably indicates that the current policy mix is unsustainable and that changes in exchange rate policy or other macroeconomic policies are necessary. ${ }^{7}$ Large capital inflows or fragility in the financial sector, for example, may require adjustments on several fronts, including the exchange rate, interest rates, and fiscal policies.

\section{Channels of Influence}

Intervention may affect the exchange rate through many channels. Under the signaling channel, market participants may adjust their exchange rate expectations when they perceive intervention as signaling a change in future monetary policy. Under the portfolio balance channel, the change in the currency composition of asset portfolios associated with sterilized intervention generates a change in the risk premium, which triggers an exchange rate adjustment as agents rebalance their portfolios. Under the microstructure approach, dealers are the price setters and base their pricing decisions in part on the order flow they observe, which is private information. Intervention-central bank generated order flow-may thus affect dealers' expectations and the exchange rate if they view it as informative.

\section{Signaling channel}

The signaling channel states that intervention can be effective if it is perceived as a signal of the future stance of monetary policy. In models that support this channel, the exchange rate is treated as an asset price and it is a function of the expected path of money supply. To the extent that intervention, even when sterilized, influences market expectations on future money supply, then it can influence the exchange rate. For example, the sale of U.S. dollars by a developing country central bank would lead to a local currency appreciation, not because the intervention changes the fundamental supply and demand conditions in the market, but because it signals a contractionary monetary policy (i.e., higher interest rates) in the future if downward exchange rate pressures persist.

A central bank has an incentive to follow through with policy actions that justify intervention ex post to safeguard its credibility and avoid financial losses. For instance, the central bank may tighten monetary policies if the domestic currency remains under downward pressure. The central bank would put its reputation and capital at stake either because it wants to signal

${ }^{7}$ In fact, the "Principles of Fund Surveillance over Exchange Rate Policies" mandated by the IMF's Articles of Agreement include large-scale intervention as one of the developments that can trigger a discussion with a member country about its exchange rate policy (IMF, 2002). 
a policy change that would not be credible otherwise or because it believes, based on its information advantage, that the level and direction of the exchange rate are unwarranted. Intervention, then, would aim to change expectations in line with the central bank's assessment.

The signaling channel depends in part on the institutional and policy credibility of the central bank. $^{8}$ The effectiveness of intervention through signaling relies on influencing market expectations by transmitting information on fundamentals or future policy actions.

Interventions must be perceived as credible signals (or threats) of future monetary policies to influence expectations. The signaling channel is most effective when interventions are publicly announced, which enhances the visibility of intervention, thus strengthening the central bank's policy signal.

The signaling channel, however, may be less effective in developing countries. First, central banks in many developing economies are at a disadvantage with respect to institutional and policy credibility. They lack the record of prudent macroeconomic management that underpins the strong credibility of monetary authorities in advanced economies. As such, the relative size of their interventions, ceteris paribus, may have to be greater to "buy credibility" for their signal of commitment to a certain course of future monetary policies (Mussa, 1981). Second, ongoing structural shifts in many developing economies-among them financial deepening, economic opening, private sector orientation, and shifts in the exchange rate regime-make it difficult to establish predictable and stable links between real and financial variables, and therefore, between intervention and future monetary policies. However, many developing country central banks enjoy offsetting advantages, including the ability to intervene in relatively large amounts and an information advantage over the market.

\section{Portfolio balance channel}

According to the portfolio balance channel, intervention can be effective by altering the currency composition of agents' portfolios. The model's key assumptions are that domestic and foreign currency denominated government securities are imperfect substitutes and market participants are risk averse. As a result, investors demand a risk premium on the bonds denominated in the riskier currency (which constitutes a violation of the uncovered interest parity condition). ${ }^{9}$ In this framework, a sterilized intervention operation alters the relative supply of domestic versus foreign currency securities, leading agents to rebalance

\footnotetext{
${ }^{8}$ The lack of credibility may also increase the likelihood of speculative attacks against the central bank (Sarno and Taylor, 2001). For instance, when the central bank intervenes to defend an unsustainable exchange rate (which may be called "adverse signaling"), market participants may engage in speculative trading against the central bank.

${ }^{9}$ The literature on violations of uncovered interest parity gives indirect support to the portfolio balance channel (See Obstfeld, 1990, and Dominguez and Frankel, 1993b).
} 
their portfolios to equalize risk-adjusted returns, which in turn, causes a change in the exchange rate. The exchange rate serves as the adjustment mechanism for risk-adjusted returns when base money and interest rates remain unchanged following sterilized intervention. $^{10}$

Unlike the signaling channel, the portfolio balance channel does not require credibility as a precondition for effectiveness. As such, it potentially can be more potent in some developing economies, where policy credibility is lower, domestic currency debt is an imperfect substitute for foreign currency debt, and interventions are large relative to foreign exchange market turnover. ${ }^{11}$

\section{Microstructure channel}

The microstructure approach provides a new window into the functioning of foreign exchange markets and the effectiveness of intervention (Lyons, 2001). ${ }^{12}$ Microstructure finance analyzes the impact of "order flow" on exchange rates. Aggregate order flow is the balance of buyer-initiated and seller-initiated orders; as such, it is a measure of net buying pressure in the foreign exchange market (Evans and Lyons, 2002, and 2003). In this framework, analyses of intervention's effectiveness focus on the extent to which central bank trades affect aggregate order flow.

According to the microstructure approach, central banks are uniquely positioned to affect the transmission of fundamentals to the exchange rate through order flow. Central bank intervention can cause market participants to change their expectations on the future path of the exchange rate and lead them to modify their net open foreign exchange positions,

${ }^{10}$ Consider the case in which the Federal Reserve (Fed) targets a stronger U.S. dollar against the Japanese yen. The Fed would sell the Japanese currency by liquidating its yendenominated bonds and simultaneously buy domestic dollar-denominated bonds, leaving domestic base money and interest rates unaffected. These operations would increase the relative supply of foreign (yen) debt relative to domestic (dollar) debt held by the market, thus requiring an adjustment in the expected rate of return of yen-denominated debt to induce investors to hold more of it. Since monetary conditions have not been affected in either market, the expected return on yen debt (and the risk premium) can only change through an exchange rate adjustment.

${ }^{11}$ The degree of substitutability between domestic and foreign currency debt is inversely related to the size of the risk premium. The lower the degree of substitutability, the more effective intervention is, other things constant.

${ }^{12}$ The market microstructure literature emphasizes the effects of order flow, market participants, information asymmetries, trading mechanisms, liquidity, and price discovery in the foreign exchange market (Lyons, 2001). 
triggering a change in aggregate order flow well in excess of the central bank's contribution. Official intervention's impact on order flow and exchange rates can be greater in the presence of noise traders, which follow past trends, and often trade in a correlated fashion (Hung, 1997). Central bank intervention, even in small amounts, can trigger a tide of buy or sell orders by trend-chasing traders. Interventions need not be announced and should be timed to maximize the exchange rate impact. Intervention in this context may also lead to higher volatility, which can help promote a sense of two-way risk in the market.

Official intervention's impact on market expectations can be even greater if the central bank is perceived to have privileged information. ${ }^{13}$. When central banks are perceived to be more knowledgeable about future monetary and exchange rate policies or better equipped to monitor and interpret fundamentals, such as balance of payments trends, market participants may try to "learn" from central bank trades. In this context, central bank intervention emits information to the market. Put otherwise, order flow serves as the vehicle through which the market aggregates information. To the extent that central bank initiated order flow transmits information, it ignites an even greater flow of foreign exchange orders, thus "impounding information into prices" (Lyons, 2001).

The microstructure channel also emphasizes that the size of intervention relative to market turnover is a determinant of intervention's effectiveness. In principle, the larger the intervention is relative to market turnover, the higher will be its price impact. Thus, intervention has the potential to be more effective in developing countries, where foreign exchange markets are less liquid.

\section{B. Trends and Experience in Foreign Exchange Intervention}

Central banks in most advanced economies and some emerging market economies hardly intervene. The central banks of the countries issuing international reserve currencies-including the U.S. Federal Reserve and the European Central Bank (ECB)—seldom intervene anymore, with the exception of the Bank of Japan (BOJ). The trend among other advanced economies is similar. Although the Bank of Canada actively intervened for many years, it has not intervened since 1998. The Reserve Bank of New Zealand has not intervened since 1985.

Some emerging market economies have followed suit. The Bank of Israel has not intervened since 1997 , despite its strong presence in the market in the early 1990s. The South Africa Reserve Bank, which pursued an active intervention policy in the 1990s, particularly in the forward markets, now mainly purchases proceeds from government external borrowing and privatization and intervenes to strengthen its net reserve position. The above-mentioned

${ }^{13}$ Even if the central bank does not have an information advantage, its interventions may still be effective so long as market participants believe that it has inside information and intervenes based on it. 
central banks generally enjoy a high degree of credibility and have monetary policy frameworks that do not use the exchange rate as an intermediate operating target.

In sharp contrast, many developing economies still intervene actively in the spot foreign exchange market according to the IMF's 2001 Survey on Foreign Exchange Market Organization (Canales-Kriljenko, 2003a). ${ }^{14}$

The discrepancy between exchange rate flexibility and intervention practices may stem in part from the aversion to excessive exchange rate volatility in developing countries. Calvo and Reinhart (2002) document how developing countries tolerate greater volatility in international reserves, domestic interest rates, and commodity prices than in exchange rates. At the same time, Calvo and Reinhart find that changes in domestic interest rates, as opposed to interventions in the foreign exchange market, are used increasingly more frequently in defense of exchange rates.

More importantly, intervention in the foreign exchange market may be more effective in developing countries than in advanced ones, despite the weaker credibility among the former (Canales-Kriljenko, 2003a). There are several reasons why this may be the case:

- In contrast to advanced countries, many developing countries intervene in amounts that are significant relative to market turnover, base money, and bonds outstanding. Their central banks are usually large customers in the foreign exchange market, especially where the government is a principal source of foreign exchange earnings. ${ }^{15}$ Moreover, they use a variety of foreign exchange, monetary, and banking regulations that effectively constrict the size of the market, increasing the central bank's relative size in it. ${ }^{16}$

- Owing to exchange and capital controls, central banks in many developing countries may possess a greater information advantage over other market participants, compared with central banks in advanced economies. This advantage may stem from, inter alia, financial reporting requirements, which enable the central bank to observe

\footnotetext{
${ }^{14}$ The survey is the most comprehensive of its kind conducted in recent years. (See also Cheung and Chin (1999) and Neely (2000).) The survey was sent to all 160 member countries that were classified as "developing" or "in transition" and had a response rate of 60 percent. The respondents accounted for 85-90 percent of GDP and external trade among all developing and transition economies in 2000 (Canales-Kriljenko, 2003a).

${ }^{15}$ This is particularly relevant for many commodity exporters in developing countries

${ }^{16}$ Regulations that constrict the size of the foreign exchange market include capital controls, surrender requirements, prohibitions on interbank foreign exchange trading, and limits on net open foreign exchange positions.
} 
aggregate order flow in the market and the net open positions of financial intermediaries, in most cases with a lag.

Country experiences with currency crises in the $1990 \mathrm{~s}$, however, illustrate the limits of intervention as a policy instrument. Mexico's year-long defense of its crawling peg in 1994 ended suddenly when the market belatedly observed the central bank's depleted reserve position. Thailand's defense of the baht in the first half of 1997 through interventions failed, virtually depleting the central bank's net international reserves. Brazil's defense of the crawling band through spot and forward market intervention could no longer be sustained against strong market pressures in late 1998 and early 1999.

The effectiveness of intervention in the long run is thus primarily a function of the sustainability of exchange rate policies and underlying macroeconomic policies. However, despite their interdependence, it is important to distinguish between intervention and exchange rate policy. Currency crises shed light on the sustainability of exchange rate policies, but not necessarily on the effectiveness of intervention per se. To the extent that intervention fails owing to unsustainable exchange rate policies, the source of failure lies not in intervention as an instrument itself, but in the policy mix underpinning the targeted exchange rate.

Empirical evidence on the effectiveness of sterilized intervention through the signaling and portfolio balance channels is mixed, although more recently, the pendulum has swung in its favor (Sarno and Taylor, 2002). Most of the evidence, however, is based on advanced country experience, particularly the United States, Germany, Japan, Canada, and Australia. Empirical evidence for developing countries is scant and further studies are needed to address intervention's effectiveness.

There are several practical difficulties in empirically studying the effectiveness of intervention in developing countries. ${ }^{17}$ First, there is limited publicly available data on intervention. Second, since many developing countries actively manage their exchange rate from fear of floating, the low variability of the exchange rate renders standard methodologies inadequate for testing the effectiveness of intervention. In addition, intervention may respond to exchange rate fluctuations and, at the same time, have an effect on exchange rates, which makes it empirically difficult to disentangle the impact of intervention on the exchange rate (i.e., the simultaneity problem). Finally, unlike in advanced countries, it is far more difficult to control for changes in policy reaction functions and central bank credibility because of the relatively frequent structural breaks in the exchange rate regime and monetary policy framework.

${ }^{17}$ See Canales-Kriljenko, Guimarães, and Karacadağ (2003) and Domac and Mendoza (2003) for a discussion of the empirics of intervention in developing countries. 


\section{Key Lessons from the Literature and Selected Country Experience}

The key lessons on intervention from the literature and selected country experience are as follows:

- Intervention is not an independent policy tool. It cannot generate permanent changes in exchange rates when intervention objectives are inconsistent with macroeconomic policies.

- Intervention may be used to address unwarranted exchange rate movements stemming from temporary shocks. Intervention can also complement efforts to place the macroeconomic policies on a sustainable path by resisting disruptive changes in the exchange rate, but only if there is a credible commitment to, and tangible progress on, macroeconomic adjustment.

- Institutional and policy credibility is an important determinant of the effectiveness of intervention. Credibility may enhance the effectiveness of intervention and even obviate the need for it.

- Central banks in most advanced economies and some emerging market economies rarely intervene anymore, despite their strong institutional and policy credibility. This reflects intervention's limited effectiveness in deep and efficient foreign exchange markets, where market failures are rare.

In sum, intervention can play a role in stabilizing exchange rates, provided that the latter are consistent with underlying macroeconomic policies. Governments should make efforts to build policy credibility and develop liquid foreign exchange markets, which can help minimize instances of misalignment and disorderly markets, and the need for intervention.

\section{INTERVENTION OPERATIONS: POLICY IsSUES}

The conduct of foreign exchange intervention, in practice, requires the development of a comprehensive set of policies and guidelines on a wide range of operational issues at the policy, technical, and administrative levels. At the policy level, decisions have to be made on the objectives of intervention, the degree of transparency, and the criteria for determining the timing and amount of intervention.

\section{A. Objectives}

Central bank intervention policies should define the objectives of intervention in precise terms. Defining intervention objectives, in turn, involves two sequential steps: specifying the exchange rate measures to be used and selecting an exchange rate target, if any. Exchange rate measures may include the nominal bilateral, nominal effective, real bilateral or real effective exchange rate. The exchange rate target may be a point-in-time level or a range within which the central bank keeps the exchange rate. Even under independently floating 
exchange rate regimes, the central bank may cap the rate of change it is prepared to permit over a certain period, such as one day. Ensuring precision in intervention objectives is critical to its successful execution and to assessing its effectiveness ex post. In practice, intervention has been pursued to achieve one or more of the following objectives:

- Correct misalignment or stabilize the exchange rate at predetermined levels or within targeted rates of change;

- Calm disorderly markets, including exchange rate volatility and market illiquidity;

- Accumulate reserves; and

- Supply foreign exchange to the market.

Correcting exchange rate misalignments is a high priority for central banks for well-known reasons. Real exchange rate overvaluation can undermine export competitiveness and weaken a country's external liquidity position, while an undervalued exchange rate may create inflationary pressures.

Even without misalignment, sharp exchange rate movements may be costly. They may raise the cost of external trade and dampen trade flows, particularly in economies where hedging opportunities are limited. ${ }^{18}$ Moreover, where credibility is lacking and the exchange rate serves as an anchor for inflationary expectations, the exchange rate is considered a symbolic and visible measure of a government's success in macroeconomic management; hence its stability assumes paramount importance. The stronger pass-through from exchange rate fluctuations to inflation in developing economies makes them less tolerant of exchange rate instability compared to advanced economies (Calvo and Reinhart, 2002). Intervention thus can serve to smooth volatility and avoid destabilizing inflationary expectations. Moreover, the balance sheet exposure of financial and nonfinancial enterprises to exchange rate risk arising from foreign currency debts adds to the costs of volatility in developing economies.

Disorderly markets involve a collapse of liquidity, where market intermediaries face difficulties matching suppliers with end users of foreign exchange. If market illiquidity persists, it can potentially have serious adverse effects on the real economy and therefore is usually not neglected for extended periods. Tolerance towards occasional episodes of

\footnotetext{
${ }^{18}$ However, these concerns may be unwarranted. Dominguez and Frankel (1993a) cite numerous studies in which the effect of exchange rate volatility on trade is small or nonexistent. More generally, the research surveyed in Rogoff (1999) indicates that the exchange rate regime and exchange rate volatility do not have detectable effects on output and trade. More recent studies on the small open economies of Ireland and New Zealand also find that exchange rate volatility has little or no impact on trade and investment (Bjorksten and Brook, 2002, and Bredin and others, 2002).
} 
illiquidity, however, is necessary to allow markets to self-correct and to expose market participants to the risks inherent in trading financial assets.

Market illiquidity can be detected by a number of indicators, including: (i) an acceleration in the pace of exchange rate changes; (ii) unwarranted increases in exchange rate volatility; (iii) a widening of bid-offer spreads; and (iv) sharp changes in the level and composition of turnover. However, these can result from changes in economic fundamentals or the arrival of new information, which may not warrant intervention. Possible ways of interpreting trends in the foreign exchange market are discussed in the next section.

Intervention aimed at addressing exchange rate levels and disorderly markets should be constantly assessed in light of the nature of the shocks to the economy, the macroeconomic policy mix, the degrees of capital mobility and dollarization, and available international reserves. For example, resisting exchange rate depreciation out of fear of misalignment may not be feasible in the face of sharp capital outflows when international reserves are low. The same applies when a bank run occurs in a country where the central bank plays the role of lender of last resort. In general, policy makers should constantly assess the feasibility of the objectives given the macroeconomic policy framework and the type of shock that has led them to consider intervening.

Reserve accumulation can be a high priority, especially in the aftermath of a currency crisis. It is particularly prevalent in developing countries trying to build investor confidence and strengthen their debt repayment capacity and external liquidity position. ${ }^{19}$ Most IMFsupported programs include targets on net international reserves to prevent them from being depleted in defense of an unsustainable exchange rate and to bolster the government's creditworthiness through higher reserve coverage of imports and short-term debt. Strengthening repayment capacity helps countries reduce their dependence on bilateral and multilateral funding by regaining access to international capital markets.

Central banks in some developing countries mainly intervene to supply foreign exchange to the market. This is especially true when the central bank is the foreign exchange agent of the public sector, and state enterprises (SOEs) are major exporters accounting for a high share of the country's foreign currency earnings, as in oil-producing countries. ${ }^{20}$ In principal, SOEs are like any other corporate customer and can deal directly in the foreign exchange market through commercial banks. In practice, however, SOEs often lack the skilled personnel in

${ }^{19}$ Strong external liquidity can help offset weak country fundamentals and reduce vulnerability to external shocks (Bussiere and Mulder, 1999). Moreover, a country's external liquidity position is a key determinant of its sovereign creditworthiness (Mulder and Perrelli, 2001).

${ }^{20}$ For a discussion of the issues involved in managing foreign exchange receipts in oilproducing countries, see Fasano (2000). 
treasury operations to effectively manage their foreign currency assets and liabilities, including the timing of their foreign exchange purchases and sales. This task is usually performed by the central bank, which has experience in dealing with the foreign exchange market. The centralization of the public sector's foreign exchange operations in the central bank has the added benefit of avoiding lumpy sales and purchases of foreign exchange by SOEs, which can disrupt the market. ${ }^{21}$

\section{B. Amount and Timing}

There is no simple rule for determining the timing and amount of intervention. It is a highly subjective exercise based on several factors, including the nature and duration of shocks, observable market indicators, market intelligence, and available reserves. However, some general principles can provide guidance to the authorities' decisions.

\section{Rules Versus Discretion}

Central banks need to have some degree of discretion in determining when and in what amounts to intervene. Discretion allows the central bank to accommodate market conditions and gives it room for tactical maneuver, although policy rules can serve as rules of thumb. Discretion is critical for several reasons:

- A long-term commitment to an intervention policy rule is not necessary when a commitment already exists to another nominal anchor, such as in an inflationtargeting framework.

- $\quad$ Market participants may take advantage of the central bank when its operations are bound by strict rules. Even if the authorities do not announce the policy rule, market participants can often discern it and speculate against the central bank, possibly generating losses for it.

- The optimal intervention rules discussed in the literature have limited application for practical purposes. ${ }^{22}$ Given an estimated model for exchange rate determination, an optimal policy rule that yields the amount of intervention at a particular moment in time can be estimated. However, there is no consensus on validity of these models and the assumptions on which they are based.

${ }^{21}$ Centralizing the public sector's foreign exchange operations in the central bank has some drawbacks, however. It can give rise to conflicts of interest between the central bank's policy goals and its fiduciary responsibilities to those entities it serves as an agent.

${ }^{22}$ See Boyer (1978), Buiter (1979), Jones (1984), Roper and Turnovsky (1980), and Turnovsky and Grinols (1996). 
- Qualitative information obtained from market intelligence can help the authorities decide the amount and timing of intervention, but its interpretation requires considerable judgment.

Rules-based intervention may be appropriate for a short period under certain circumstances. Brazil's ruled-based intervention policy, which ex ante limited the central bank's sales of foreign exchange to US $\$ 50$ million a day between July and December 2001, was effective in filling the estimated balance of payments gap arising from a sharp reduction in capital inflows, without giving the impression that the central bank was targeting the exchange rate. Similarly in Turkey, foreign exchange sale and purchase auctions, whose timing and amount are determined and announced ex ante, have been an effective and transparent mechanism for reinforcing the central bank's commitment to a floating exchange rate regime.

Over time, however, many central banks that have experimented with rules-based policies have abandoned or modified the rules to allow for some discretion. For example, Canada's mechanical intervention policy of the 1990s was modified in 1995 and abandoned in 1998 to provide the central bank with greater discretion and to reduce the frequency of intervention (Murray, Zelmer, and McManus, 1996). ${ }^{23}$ Similarly, Brazil's rules-based intervention policy, which was revived in mid-2002, was subsequently relaxed in order to give the central bank more discretion over how, when, and by how much it could intervene in the spot market as it responded to changing market conditions.

\section{Market Indicators and Intelligence}

The authorities should monitor a combination of market indicators and intelligence, and use a variety of analytical methods and economic models before making intervention decisions. Criteria for interpreting observable market indicators and their implications for the timing of intervention are discussed in the subsection on "general considerations on timing" below.

Market intelligence -including information on the underlying sources of foreign exchange demand and supply, large customer transactions, order flow, and the market's view of the balance of payments outlook - is a critical complement to observable market indicators. Market intelligence gathered from market participants enables monetary authorities to obtain information on critical but unobservable (on a real time basis) determinants of exchange rates, such as order flow. Traders are in constant contact with customers, and therefore, can offer key insights on large commercial transactions, the sources and underlying reasons for customer orders, and on how the market may be reacting to a shock. Market intelligence can be gathered through daily telephone surveys, through informal contact with traders, or a combination of the two.

${ }^{23}$ Beattie and Fillion's (1999) study on Canada also found that rules-based intervention did not reduce exchange rate volatility, though the existence of a non-intervention band provided a small stabilizing influence. 


\section{Considerations on Amount}

The amount of foreign exchange intervention should not be determined from a policy rule. Central banks often determine "effective" amounts through trial and error. Intervention affects order flow, the risk premium, and expectations, all of which interact with each other and can impact the exchange rate (Figure 1). The intervention amount, in principle, should be as large as necessary to achieve the targeted exchange rate and usually must be a multiple of the typical market order. The intervention amount depends, in part, on its effect on exchange rate expectations. A change in expectations can cause market participants to modify their net open foreign exchange positions and create order flow in favor of the targeted exchange rate, lowering the amount needed for intervention.

The cumulative amount of intervention in defense of the exchange rate should be reviewed whenever it approaches a predetermined benchmark over a given period. Moreover, the central bank should avoid conducting one-sided intervention on a continuing basis. It is vital to adjust policies to resolve the underlying causes of imbalances in order flow. In this context, intervention can provide an early warning indicator that the policy mix is unsustainable. This is one of the rationales for setting a floor on reserves under IMFsupported programs (Mussa and Savastano, 1999).

The stock of available reserves constrains the cumulative amount of intervention to defend the currency. Moreover, in some developing economies, the scarcity of reserves is a major constraint even in the short run. When facing currency depreciation pressures, the central bank faces a potential run down of reserves, which can undermine investor confidence even further.

Figure 1. Intervention and Exchange Rate Impact

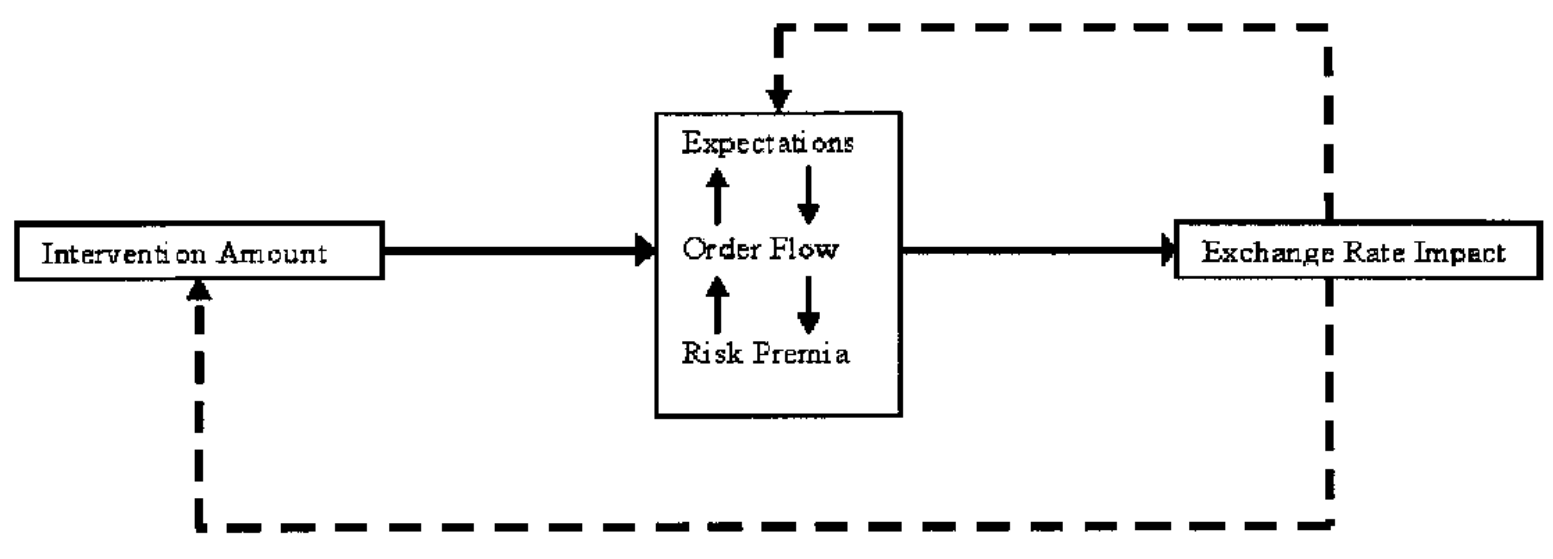

Central banks generally should refrain from financing intervention when net international reserves are low. Externally financed intervention under such circumstances creates unacceptably high risks for the central bank. For example, adjustment efforts to reduce 
macro-imbalances may be delayed if financing operations are opaque. Once access to financing dries up, both expectations and reserves are likely to deteriorate sharply. This, in turn, can give rise to positive feedback trading and to an overshooting of the exchange rate. Moreover, large externally financed intervention exposes the central bank or national authorities to exchange rate and rollover risks.

The scope for conducting large-scale official intervention is greater for foreign exchange purchases than for foreign exchange sales. Foreign exchange purchases can always be financed by printing money, which may or may not be sterilized depending on the monetary framework. However, this can either affect the inflation objectives of the authorities (if unsterilized) or generate substantial interest rate costs that would weaken the central bank's balance sheet (if sterilized). ${ }^{24}$

\section{Considerations on Timing}

Like intervention amounts, determining the timing of intervention is a highly judgmental and subjective exercise. It involves an analysis of observable market indicators and available market intelligence, against the background of the central bank's unique experiences and country-specific circumstances. Economic models and policy rules can serve as input into a decision-making process that still requires considerable judgment and is subject to large margins of error. The timing of intervention ultimately depends on the central bank's assessment of the presence of exchange rate misalignment and disorderly markets.

\section{Exchange rate misalignment}

Despite a voluminous literature on exchange rate misalignment, there is no consensus on a methodology to compute the equilibrium exchange rate (Chinn, 2001, Isard and others, 2001, and Hinkel and Montiel, 1999). Readily available indicators that can be used to uncover signs of exchange rate misalignment include the nominal and real effective exchange rates, productivity and other competitiveness indicators, the terms of trade, the balance of payments, and interest rate differentials. However, these indicators often do not allow policy makers to identify the presence or magnitude of misalignment precisely enough to justify intervention.

The analysis of fundamental trends is particularly vital to identifying the nature of shocks to the economy, which may be important determinants of the timing of intervention. Permanent shocks to domestic monetary conditions or the terms of trade, for example, would be expected to generate a change in expectations and an adjustment in the exchange rate. A sharp change in the exchange rate initiated by a permanent shock need not be resisted by intervention, unless the movement threatens to trigger positive feedback trading. Then

${ }^{24}$ High interest rates can be particularly damaging if the stock of public sector debt is large and its service is affected significantly by variations in nominal interest rates. 
smoothing may be warranted. By contrast, temporary shocks to the economy that do not significantly affect macroeconomic fundamentals may call for intervention if the shock causes unwarranted fluctuations in the exchange rate.

\section{Disorderly market conditions}

Detecting disorderly markets is equally challenging. An acceleration in exchange rate changes is a prime symptom of market illiquidity, where predominantly one-way customer orders become difficult to match, reducing the number of transactions, and ultimately leading to a complete market standstill. Rapid price movements can also occur in a liquid market, but still be a matter of concern because of their potential to create positive feedback trading, which may cause the exchange rate to overshoot and set the stage for a sharp price reversal in the future. Under this scenario, it is the potentially self-fulfilling dynamics of price changes and their potential to create destabilizing shifts among multiple exchange rate equilibria that may necessitate central bank intervention.

Widening bid-offer spreads signal heightened uncertainty in the level of the exchange rate, which in turn, may diminish market liquidity. Dealers typically raise bid-offer spreads to protect against exchange rate volatility and unexpected order flow. The high level of price uncertainty may keep market participants from transacting until the direction of the exchange rate becomes clearer, possibly through central bank intervention. Some central banks attach greater importance to widening bid-offer spreads than to abrupt exchange rate changes because the price uncertainty implied by large spreads may be a greater threat to market liquidity. Larger bid-offer spreads may indicate that dealers are finding foreign exchange intermediation more risky or costly, a situation that may lead them to withdraw from supplying liquidity to the market. Although widening spreads are more likely to be associated with diminishing market liquidity, their absence does not necessarily imply that markets are liquid. Where one-sided trading produces sharp, unidirectional, and continuous changes in the exchange rate, the market anomaly would be reflected in sharp level changes, while spreads remain low. Bid-offer spreads thus must always be analyzed in conjunction with other indicators.

The composition and magnitude of turnover in the foreign exchange market also provide important clues on liquidity and trading dynamics. In particular, a rise in interbank trades relative to customer-bank turnover may indicate that dealers are facing difficulties matching customer-initiated foreign exchange orders with final counterparties. ${ }^{25}$ This may also be symptomatic of "hot potato" trading, where interbank activity rises as dealers try to pass on or hedge the exchange rate risk associated with a previous trade, with few or no participants

${ }^{25}$ We thank Mark Zelmer for suggesting this indicator. 
willing to remain exposed. ${ }^{26}$ Trading may once again collapse altogether if orders become entirely one-sided. In this case, central banks should intervene to prevent a collapse of liquidity in the foreign exchange market.

Exchange rate volatility is another vital indicator of market conditions. ${ }^{27}$ However, it is not necessarily a source of concern per se unless other indicators such as widening bid-offer spreads suggest disorderly market conditions. Volatility often reflects, among other things, uncertainty in economic policies and other fundamental determinants of exchange rates, which the market may be struggling to price accurately. To the extent that price discovery and volatility occur in an orderly (liquid) market, central bank intervention would be unwarranted. Moreover, tolerance for some degree of volatility is essential. Insulating the economy from volatility would otherwise deprive market participants from learning to cope with volatility and to manage exchange rate risks. The moral hazard problem associated with the perception of an implicit exchange rate guarantee, in turn, may lead to liability dollarization and balance sheet vulnerability. Therefore, central banks must strike a careful balance between exchange stability and volatility, confining potential interventions to only extreme degrees of price movements. By contrast, if volatility reflects widening bid-offer spreads, heightens the risk of positive feedback trading, or threatens price stability, then the central bank may have reason to act.

Distinguishing disorderly markets from normal market dynamics and setting predetermined trigger points for intervention, however, is extremely difficult. The lack of consensus on determinants of exchange rates at high frequencies heightens the challenge of ascertaining market conditions. Trends in volatility, spreads, and turnover can only be interpreted in the context of events and shocks that may be driving them. For example, volatility that amounts to a market disturbance in one market can be typical behavior in another market. As such, it is difficult to predetermine when volatility and spreads are excessive and turnover is inadequate with enough precision and certainty to warrant intervention. They are always market specific and state dependent. The challenge is compounded by the constantly changing nature of shocks to the economy and of market dynamics, including the growing diversity of market participants. Nonetheless, the central bank should set benchmarks for various market indicators to enhance its capacity to respond quickly to developments, when needed. $^{28}$

${ }^{26}$ Hot potato trading may be efficient when dealers share the risk borne out by trading with the end-users of foreign exchange. In this case, excessive turnover need not be symptomatic of an inefficient market.

${ }^{27}$ There are several measures of exchange rate volatility. Widely used measures include implied volatility from option prices and time series measures such as the GARCH model (Jorion, 1995). The analysis below does not rely on any particular measure of volatility.

${ }^{28}$ Benchmarks on the level of exchange rate need to take into account the degree of volatility in normal times. 
To the extent that some flexibility exists within the day (or possibly week) in terms of timing, intervention should occur in a liquid market. When the market is illiquid, intervention may have a large price impact, but it can also disrupt trading conditions. Dominguez (2003) notes that interventions during heavy trading volume and closely timed to scheduled macroeconomic announcements are the most likely to have large effects on the exchange rate.

\section{Reserve Accumulation and Foreign Exchange Supplying}

Unlike exchange rate related objectives, reserve accumulation and supplying foreign exchange to the market are much easier to define and measure. The challenge is to minimize the price impact of intervention, while accumulating reserves and supplying foreign exchange. Periodic foreign exchange auctions are one way the central bank can minimize intervention's price impact, though such auctions, where possible, should not be automated according to a predetermined schedule to avoid gaming by the market.

Market conditions should be taken into account when intervening to accumulate reserves or supply foreign exchange. For example, the supply of foreign exchange should be timed during downward pressure on the currency, while interventions to accumulate reserves should coincide with an appreciating currency, where possible. When trade-offs among intervention objectives are unavoidable, intervention should be conducted according to the priority of objectives.

\section{Transparency}

Transparency in intervention policies and objectives can enhance the credibility of the central bank by holding it accountable for its record of policy implementation (Geraats, 2001). When central bank credibility is lacking, transparency can be instrumental to building reputation, provided there is a credible commitment to prudent macroeconomic policies and central bank independence.

The degree of transparency on intervention operations may vary with the specific objectives of intervention. The optimal level of transparency also depends on whether or not the central bank undertakes intervention with the aim of affecting the exchange rate (Dominguez and Frankel, 1993b). For example, the central bank may prefer to intervene secretly while adjusting its own portfolio or replenishing reserves. Alternatively, the central bank may not want to jeopardize its credibility over a rate that subsequently fails to hold (Enoch, 1998). By contrast, if the central bank has strong credibility and its intervention objective is to influence the exchange rate, its presence in the market should be revealed so that it can benefit from the signaling effect.

Central banks usually have considerable discretion in choosing the degree of transparency of intervention. They can, but may not elect to, disclose various aspects of their intervention 
operations, including their presence in the market, the amount of intervention, transaction prices, intervention instruments, and the number of operations.

Regardless of whether the central bank announces its presence in the market, it should not reveal its trading tactics. "Tactical ambiguity" with respect to the exact timing and amount of intervention will heighten prospects for achieving the intervention objective most efficiently, i.e., with the minimum amount of intervention as possible. Revealing its trading tactics may otherwise create opportunities for market participants to reap riskless profits (i.e. the market can profit by anticipating and internalizing the central bank's actions in their own trading tactics). In some circumstances, the central bank can disclose some aspects of its interventions (e.g., whether it will buy or sell), but it still must ensure that the information divulged does not enable market participants to game it.

There are other reasons why the central bank may wish to intervene secretly. Central banks sometimes may want to calm disorderly markets caused by herd behavior by introducing a sense of two-way risk in the market. In this instance, the central bank is not committed to a particular exchange rate level and may not want to put its reputation at risk. It also would want to retain an element of surprise, especially when the scale of intervention is modest relative to the daily turnover in the market (Sarno and Taylor, 2001).

Similarly, central banks may aim to forestall a currency from breaking a resistance level (i.e., the level at which stop-loss trading models may trigger selling) (Dominguez and Frankel, 1993b). In the same vein, where the exchange rate is managed within a band, the central bank may intervene intramarginally to preempt speculative pressures from emerging once the rate approaches the edge of the band (Enoch, 1998).

The extent to which tactical ambiguity is successfully maintained depends on the timing of disclosure, the choice of counterparties, and the structure and liquidity of the foreign exchange market. In terms of timing, official intervention may become public in various ways, including (i) through policy announcements; (ii) by revealing the central bank's presence during the operations; (iii) by selecting the most visible trading platforms and counterparties; (iv) by confirming or denying ex post press reports; and (v) by reporting statistical information on exchange rates, with a lag.

The central bank may benefit from concealing its identity before striking a deal to avoid discriminatory treatment and to secure the best possible rate for its trade. This can be achieved by trading in electronic broking systems or through an agent, although this may be difficult in other trading platforms. For example, as soon as the central bank asks for a quote, its identity is revealed, though routine inquiries can weaken the perceived link between its inquiries and intervention. Intervening through voice brokers faces other challenges (see Box 2). Concealing central bank trades is much harder when the bulk of foreign exchange transactions are concentrated in a few market participants. Even if successfully maintained, central bank anonymity can have adverse side effects. For example, market makers may widen the bid-offer spread when they attach some probability that they may be trading with the central bank (which is an adverse selection effect of dealing with an informed agent). 
The greater the size of intervention relative to market turnover, the more difficult it is to keep intervention secret. This is even more notable in many developing countries where foreign exchange intervention is large relative to turnover. In addition, in several developing countries, the banking system is highly concentrated, allowing the main participants to infer the central bank's presence. Market participants may also get some indication of the central bank's participation in the market through the evolution of net international reserves, particularly in countries that disclose their reserve data in a timely manner.

The transparency of intervention practices varies across countries. The central banks in the G-3 countries have enhanced the transparency of their interventions. Since the mid 1990s, interventions by the U.S. Federal Reserve have been reported on a quarterly basis and highly publicized in the financial press. ${ }^{29}$ The ECB announces some of its interventions, although the information contained in the announcements is limited and does not include amounts and timing. The BOJ does not announce its interventions, but reports the amounts and exchange rates ex post (Ramaswamy and Samiei, 2000, and Ito, 2002).

In emerging markets, central bank practices on secrecy are mixed (Canales-Kriljenko, 2003a). About half of the central banks in these economies that responded to a survey on intervention practices announce their presence in the market. About 25 percent of survey respondents indicated that they publish data on their interventions, in some cases with a lag.

\section{Market Microstructure}

Central banks may organize the foreign exchange market in a way that enhances the effectiveness of intervention. They may define core elements of the market, including participants, information flows, and trading mechanisms (Canales-Kriljenko, 2003a and $2003 \mathrm{~b}$ ). By restricting participation to certain types of institutions, central bank regulations may temper speculative activities, albeit at the expense of narrowing the range of hedging options in the market.

Central banks can also create an information advantage for themselves, for example, by selecting trading mechanisms. Most central banks establish extensive reporting requirements on banks' foreign exchange operations and net open positions and manage the disclosure of information obtained from them. A few also only allow foreign exchange trading mechanisms in which they have privileged access to information from all transactions and can participate in the market like any other authorized dealer. In a few countries where foreign exchange receipts are surrendered to the central bank, centralized auctions are

\footnotetext{
${ }^{29}$ The U.S. Federal Reserve reports its intervention activity on the web quarterly, and releases daily intervention figures with a one year lag. Hung (1997) estimates that around 40 percent of the Federal Reserve's foreign exchange interventions during the period 1985-89 were not announced.
} 
conducted periodically for price discovery. In these cases, the central bank has inside information because it performs the role of auctioneer, but can simultaneously participate in the auction. Several central banks also have privileged access to information from trading in selected electronic broking and dealing systems.

Some countries use a variety of foreign exchange, monetary, and banking regulations that constrict the size of the market, potentially increasing intervention's relative size in it. For example, a few countries explicitly ban interbank trading while others allow banks to trade with each other only on behalf of their customers. This way, they limit competition in the process of price discovery and reduce the scope for interbank trading. Other countries achieve a similar outcome by performing the role of market makers with narrow bid-offer spreads that undercut competition from authorized dealers and transform the central bank into the principal foreign exchange intermediary (Canales-Kriljenko, 2003a).

While some of these regulations can make intervention more effective, they can also cause the central bank to intervene more often than it otherwise would. The central bank would have to shoulder the burden of smoothing discrepancies in foreign exchange orders, since other market participants would not have an incentive to conduct stabilizing speculation. This can potentially increase exchange rate volatility.

\section{INTERVENTION OPERATIONS: TECHNICAL ISSUES}

Decisions on the technical aspects of intervention revolve around the choice of markets and counterparties. Central banks also must strive to maximize the efficiency of intervention for a given policy level decision (e.g., the degree of transparency).

\section{A. Choice of Markets}

In choosing a market for intervention, the authorities must decide the intervention instrument (or type of foreign exchange contract), the trading location, and the currency in which to intervene.

\section{Which Markets to Intervene In-Spot, Forward, or Other Derivatives Markets?}

Intervention generally should take place in the spot market rather than in the forward market when the goal is to affect the spot exchange rate. ${ }^{30}$

${ }^{30}$ The IMF's 2001 Survey on Foreign Exchange Market Organization found that 78 percent of the responding countries conducted intervention in the spot market, while only 4 percent reported intervening in the forward market. Neely (2000) reports a similar figure for spot market intervention, but finds that about fifty percent of the respondents also intervened in forward markets. For a brief analysis of South Africa's experience with forward market 
- $\quad$ Spot market intervention directly affects the spot exchange rate. Forward market intervention relies on the transmission mechanism from forward to spot market rates, which is affected by money market conditions as well as exchange and capital controls.

- $\quad$ Spot market intervention is less susceptible to liquidity risk. Spot markets are usually more liquid and less constrained by counterparty limits than forward markets. Moreover, with increased uncertainty, forward market trading may dry up faster than spot trading due to higher credit risks at longer maturities.

In general, intervention financed through derivative instruments is not advisable. ${ }^{31}$

- $\quad$ Financing spot market intervention through swaps and other derivative contracts can lead to highly leveraged net open foreign exchange positions, exposing the central bank to exchange rate and rollover risks.

- $\quad$ Conducting intervention through derivatives, which enables the central bank to conceal intervention from the public at large, may delay necessary policy adjustments. Protracted intervention on one side of the market, in turn, can result in substantial reserve losses without achieving intervention objectives.

- The use of derivative instruments obscures the interpretation of the central bank's balance sheet even for the authorities. The complicated nature of derivative contracts, especially option contracts, makes it difficult to exert internal control on foreign exchange operations, which can elevate the central bank's risk exposure, especially in countries with weak governance.

Nevertheless, under certain conditions, intervention through derivative markets may play a role. ${ }^{32}$ For example, derivatives markets may be an appropriate source of financing intervention if the central bank:

intervention, see South African Reserve Bank (1998). For the experience of Thailand, see Moreno (1997), Lall (1997), and IMF (1998).

${ }^{31}$ For some of the risks associated with intervention in derivative markets, see the Hannoun report (BIS, 1994).

${ }^{32}$ Derivative instruments can be used to sterilize the monetary effects of intervention when monetary policy instruments are scarce, for example when the money market is not well developed or the stock of government securities is small. The central bank may also use swaps and other derivatives to manage domestic liquidity. Since foreign exchange swaps typically involve spot transactions and simultaneous reverse forward transactions, the use of foreign exchange swaps for liquidity management can in principle give rise to a large foreign 
- Understands the risks associated with derivative positions and sets adequate systems for monitoring, controlling, and managing these risks; ${ }^{33}$

- Avoids conducting protracted intervention on one-side of the market and building a persistent short net open foreign exchange position; and

- Creates the right incentives for changing the policy mix, including by disclosing periodically its positions in derivatives.

At the operational level, it is preferable to sterilize spot market intervention through swaps rather than using other derivative instruments such as forward, futures, or options when the objective is to affect exchange rates. The central bank can trade during the day in the spot market, tailoring its intervention according to market reactions, and then adjust its reserve position with a swap at the end of the day. Futures contracts are subject to margin calls that can disrupt the authorities' cash flows. Intervention in option markets is an attractive alternative but needs to be approached with care (Box 1).

exchange forward book, even if the swap operations do not have an exchange rate objective (Bartolini, 2002, and Hooyman, 1994).

${ }^{33}$ The central bank needs to adopt tools to manage its exposure to market risks. For example, the authorities should, inter alia, open a new trading book, establish a method of measuring foreign exchange exposure, conduct regular stress tests, and frequently estimate value at risk. 


\section{Box 1, Intervention Through Options}

In theory, intervention through options may be effective in reducing exchange rate volatility. Experience with this kind of intervention, however, has been limited and not well documented in the literature.

\section{Effects of Intervention through Standard Options}

Option market intervention can have an immediate effect on the exchange rate and reduce exchange rate volatility, but exposes the central bank to significant losses (Breuer, 1999). For example, to hedge its position arising from a central bank sale of foreign exchange call options, a market makcr can borrow foreign exchange up to a fraction of the notional amount, sell it on the spot market, and invest the domestic currency in the money market. ${ }^{1}$ Besides the immediate effect on the spot market, the buyer of the call option hedges its option position over time in a way that reduces exchange rate volatility. In particular, the buyer sells foreign exchange when the domestic currency depreciates and buys it when the domestic currency appreciates. In contrast, when the central bank sclls forcign exchange put options, the market maker buys foreign exchange at the outset, but its hedging behavior over time still reduces exchange rate volatility. ${ }^{2}$ As the seller of the option, the central bank is exposed to significant exchange rate losses because it is contractually obliged to sell at below market rates when the option is "in the money."

\section{Country Experiences with Other Type of Option Contracts}

Mexico auctioned U.S. dollar put options between August 1996 and June 2001, while Colombia set up a system for the auction of U.S. dollar call and put options in $1999 .{ }^{4}$ The objective of the put option sales in Mexico and one type of option contract in Colombia was to accumulate international reserves, while minimizing the disruption in the spot market. Colombia also issued other types of options contracts to smooth exchange rate volatility. In order to stem downward pressures on the local currency, spot market intervention was conducted in Mexico during the period, while in Colombia, intervention was limited to the option market. The Mexican and Colombian option contracts were not standard. For example, the strike price of the options used to accumulate reserves was not fixed but corresponded to the interbank rate of the day earlier and put (call) options could only be exercised if the exchange rate depreciated (appreciated) more than the 20-day exchange rate moving average. Werner and Milo (1998) developed a model to price the Mexican option contract and Mandeng (2003) suggests improvements to the Colombian ones. Werner (1997) found that the option intervention strategy in Mexico, as intended, did not have a significant effect on exchange and interest rates.

A standard call option gives the buyer the right, but not the obligation, to buy foreign exchange. Similarly, a standard put option gives the buyer the right, but not the obligation, to sell foreign exchange. American-stylc options can be exercised at any time before maturity while European-style ones only at maturity (Hull, 1997).

${ }^{2}$ Breuer (1999) has argued that to reduce exchange rate volatility, the central bank needs to sell (rather than to buy) options. His argument assumes that market makers take a net long option position when they buy from the central bank. In hedging long option positions over time, market makers reduce exchange rate volatility. In contrast, they increase volatility when they hedge short option positions. Zapatero and Reverter (2003) develop and calibrate a theoretical model that compares spot market with option market intervention and conclude that the latter could result in lower exchange rate volatilities at a lower reserve cost. This result, however, critically depends on the interaction between interest and exchange rates.

${ }^{3}$ The Colombian experience has been documented by Clavijo (2002) and Mandeng (2003), while the Mexican one by Carstens and Werner (1999), Galán and others (1997), Werner (1997), and Werner and Milo (1998). 


\section{Trading Location: Onshore or Offshore Markets?}

Intervention should normally take place in onshore markets where the bulk of foreign exchange trading takes place. Concentrating interventions in the domestic market helps maintain the primacy of the domestic market, and may give the central bank greater access to market information and intelligence. ${ }^{34}$ In addition, central banks can effectively address the order flow imbalance created offshore by intervening onshore.

In some cases, intervention in offshore currency markets may play a useful role. In particular, the central bank may intervene in offshore currency markets when (i) the local currency trades offshore beyond the normal working hours in the onshore market; (ii) exchange rate pressures emerge in offshore markets; and (iii) secret intervention is preferred and easier to conduct offshore.

Several operational issues must be addressed when intervening in offshore markets. The central bank may have to appoint an agent to act on its behalf, which can be a foreign central bank, the Bank of International Settlements, or a foreign or domestic commercial bank. The central bank or its agent would have to abide by the rules and regulations of the markets in which intervention takes place (including the trading protocols).

\section{Intervention Currency}

The principal intervention currency should be the international currency most widely traded against the domestic currency to reduce costs and facilitate settlement in countries following flexible exchange rate regimes. ${ }^{35}$ Intervening in the most widely traded currency pair makes it easier for the central bank to find counterparties and reduces transaction costs as measured by bid-offer spreads. In addition, settlement facilities are usually more reliable.

For most developing economies, the intervention currency is the U.S. dollar because foreign exchange trading is concentrated in the dollar (Canales-Kriljenko, 2003b). ${ }^{36}$ Countries without a conventional fixed peg to a single foreign currency, which have reported their intervention currencies in the AREAER, have adopted the U.S. dollar as their intervention

\footnotetext{
${ }^{34}$ This distinction may be immaterial since offshore currency trading seldom takes place without the ultimate participation of domestic dealers and domestic banks.

${ }^{35}$ For countries with exchange rate regimes pegged to a single foreign currency, however, the intervention currency should be the peg currency. According to the Annual Report on Exchange Arrangements and Exchange Restrictions (AREAER, 2002), this rule is adopted by all countries with pegged exchange rate regimes that have disclosed their intervention currency.

${ }^{36}$ The main intervention currency for the ECB and the Bank of Japan is also the U.S. dollar.
} 
currency. The U.S. dollar may be the main intervention currency even in countries whose trade is concentrated in the euro area and in countries whose currencies are pegged to a currency basket. Some major developing economies have publicly announced that they have included the euro as an intervention currency (see for example, Reserve Bank of India, 2000), but the U.S. dollar most likely remains the principal intervention currency.

The central bank should intervene in one foreign currency at a time to avoid the risk of cross currency fluctuations. Intervening in many currencies complicates foreign exchange operations and exposes the central bank to exchange rate risk. For example, rapid changes in cross-currency exchange rates would force the central bank to realign its intervention rates and minor delays can provide arbitrage opportunities to speculators at the expense of the central bank. Intervening in only one currency at a time does not affect the counterparties that may need other foreign currencies because major international currencies can be converted at low cost in worldwide markets (Nordman, 1997). Operationally, the central bank should announce a limited number of currencies in which it will conduct intervention and that it will intervene only in one currency at a time. ${ }^{37}$

\section{Wholesale Transfers or Retail Cash Markets?}

Central banks should intervene only in the wholesale market for transfers in the absence of exchange controls. ${ }^{38}$ Wholesale transfers reduce transaction costs by economies of scale and by avoiding transportation and warehousing costs. ${ }^{39}$ In the presence of exchange controls, central bank intervention in the retail cash market may rein in unwarranted depreciation expectations. The retail cash market, which is often linked to the parallel market rate, can become the center for price discovery and the formation of exchange rate expectations, even if it is a small fraction of trading and highly volatile. Therefore, intervention in cash markets, including parallel markets, can sometimes help prevent unwarranted shifts in exchange rate expectations.

${ }^{37}$ For example, the U.S. Federal Reserve is authorized to conduct intervention in the nine currencies listed in the document "Authorization for Foreign Currency Operations," which is reproduced in the annual report of the Board of Governors of the Federal Reserve System.

${ }^{38}$ Some electronic dealing systems distinguish among four products (wholesale transfer, wholesale cash, retail transfer, and retail cash) that could have four different prices.

However, transfers usually trade in the wholesale market and cash usually trades in the retail market.

${ }^{39}$ Differences in exchange rates between the wholesale transfer and the retail cash market mainly reflect differences in convenience and cost. 


\section{B. Choice of Counterparties}

The central bank should establish objective and transparent criteria for choosing counterparties for intervention. ${ }^{40}$ For example, the central bank should trade only with financial institutions that (i) are solvent, ${ }^{41}$ (ii) provide information on market developments and conditions to the central bank, and (iii) offer competitive two-way exchange rates to the central bank. More generally, the central bank should trade mainly with market makers, but it may find it useful to extend the range of its counterparties when exchange controls are present or competition is low.

In competitive environments without foreign exchange controls, the central bank should trade mainly with market makers. ${ }^{42}$ First, the central bank can promote the development of a fledging interbank foreign exchange market when it trades only with market makers that provide liquidity to the market by offering two-way (buying and selling) exchange rates on demand. Second, market makers can efficiently distribute the foreign exchange provided by the central bank by standing ready to trade with other authorized dealers. Third, market makers are usually able to handle large trading volumes, avoiding the need for the central bank to conduct many foreign exchange operations. ${ }^{43}$ Fourth, the central bank minimizes the chances of dealing with lesser quality counterparties. Finally, trading with market makers that routinely interact with other market participants can provide greater control to the central bank on the degree of transparency of its foreign exchange operations (Box 2).

${ }^{40}$ Some countries disclose the criteria. For details, see ECB (2000), Federal Reserve Bank of New York (2003), and Sveriges Riksbank (1999).

${ }^{41}$ Trading with solvent institutions reduces settlement risks, while allowing the central bank to control the transparency of intervention. Although the central bank can depart from standard market practice and insist on being paid first to avoid credit risk, it would have to reveal its identity beforehand, which is not always desirable.

${ }^{42}$ In a few developing economies, the law establishes the permissible central bank counterparties. Some central banks appoint the counterparties for their foreign exchange operations through a formal agreement (e.g. Sveriges Riksbank and the Federal Reserve Bank of New York). Other central banks do not appoint central bank counterparties, but trade only with authorized dealers that belong to a market maker's club. Under this arrangement, the private sector indirectly chooses central bank counterparties.

${ }^{43}$ In general, market makers are better positioned than the central bank to interact with the public at large given their ongoing customer relations with providers and users of foreign exchange. They can perform retail foreign exchange operations at a lower cost than the central bank. 


\section{Box 2. Choice of Counterparties and Transparency}

The degree of transparency of central bank intervention varies depending on whether the central bank approaches the final counterparties directly, through brokers, or through agents acting on its behalf. The central bank can better control the transparency of its foreign exchange operations when it deals with selected market makers or when they act on its behalf.

\section{Trading directly with market makers}

The central bank can impose a confidentiality requircment on these institutions as a condition for dealing with it. They will have little incentive to reveal their client's presence from fear of driving the price against themselves before unloading the positions taken on from the central bank (Enoch, 1998). After having unloaded their position, they have the incentive not to disclose the presence of the central bank if they want to keep dealing with the central bank on a regular basis. Moreover, the central bank can ask its market maker counterparties to act on its behalf to place limit orders through brokers (in amounts that can be considered normal for the turnover in the market) to increase the secrecy of the transaction. The disclosure of the market maker's identity once the deal is sealed would not reveal the presence of the central bank. Nevertheless, if only one market maker takes a contrarian's position in a one-sided market, market participants may presume that the central bank is behind these operations.

\section{Trading indirectly through brokers or agents}

It may be more difficult to control the transparency of the central bank's presence in the market when it deals with counterparties other than market makers. For example, the central bank would automatically reveal its presence in the market when it deals with many dealers on a bilateral basis, since it will have to disclose its identity to get or give a quote. The same applies when the central bank directly approaches counterparties through voice brokers. Brokers can benefit from disclosing the presence of the central bank in the market by attracting more business from market participants that value this type of confidential information. Confidentiality agreements with brokers are difficult to enforce, because it is difficult to prove whether brokers or the final counterparties disclosed the information. While brokers do not disclose the identity of the counterparties posting the best rates before the deal is struck, the identity must be disclosed for settlement to the final counterparties. Dealings with state-owned commercial banks can be interpreted as intervention on behalf of the central bank. Finally, counterparty diversification may obscure the degree of transparency about the size of intervention, but would likely increase the market's awareness of the presence of the central bank in the market because more individuals are involved.

When foreign exchange controls are present, the central bank may elect to trade directly with foreign exchange bureaus and in the parallel market. Although trading with bureaus may be a small fraction of total trading, a sharp depreciation in the bureau market can affect exchange rate expectations and move exchange rates in the interbank market. ${ }^{44}$ However, the benefit of

\footnotetext{
${ }^{44}$ When foreign exchange controls restrict access to foreign exchange for some legally permitted international transactions, a spread of more than 2 percent in the parallel or bureau foreign exchange markets would give rise to a multiple currency practice. To avoid this possibility, some countries have directly forced, through regulation, the bureau exchange rate to be set in relation to the official rate.
} 
reducing spreads in the parallel market through intervention should be balanced against the cost of dealing with riskier counterparties. The central bank should make special settlement arrangements to protect itself against credit risk.

When competition is low, the central bank may consider directly trading with the public at large to increase competition in the foreign exchange market. When the market is thin and a few authorized dealers account for the bulk of trading and are not willing to offer two-way quotes, then central bank's direct participation can intensify competition.

Central banks may want to deal directly with the public also when an unwarranted bid-offer spread is emerging in the retail market owing to insufficient competition. Some countries have experimented with authorized dealers acting on behalf of the central bank for conducting retail operations. In return, these banks receive a commission for transferring the funds to end-users.

\section{Administration and Governance}

The efficient organization of individuals, systems, and equipment can improve the effectiveness of intervention and reduce associated risks. Foreign exchange operations can be thought of as a production process that requires the management of labor and capital, and mechanisms for defining and coordinating delegated responsibilities. They also involve addressing agency and governance problems, adopting procedures to minimize operational errors, and implementing internal control systems. In addition, they require setting up the trading infrastructure, including dealing and information systems, and ensuring appropriate personnel training. ${ }^{45}$

Close coordination and reliable communication channels must exist at all the times among individuals in charge of adopting and implementing exchange and monetary policies. Communication channels must link decision makers on intervention with other policy makers whose decisions affect or can be affected by intervention. It is vital to establish a forum for discussion and decision making among these individuals to facilitate communication at critical times. The coordination between the foreign exchange and the money market desks

${ }^{45}$ A full treatment of the operational issues at the administrative level is beyond the scope of this paper. Examples of best practice are available on various websites. For example, the Foreign Exchange Committee (FEC) of the Federal Reserve Bank of New York identifies sixty principles of best practice in managing operational risk in foreign exchange (FEC, 2003). In addition, the FEC's Guidelines for Foreign Exchange Trading Activities identifies best practices for trading, risk management, and human resource administration among other issues. The Financial Markets Association (ACI)'s model code of conduct provides guidance on best market practice and personal conduct issues in the foreign exchange and other overthe-counter markets (ACI, 2002). 
can be facilitated when the two desks are in the same physical location and under common management.

The decision-making hierarchy and the chain of command must be clear, with wellestablished mechanisms for the delegation of responsibilities. Within the central bank, a small committee should make foreign exchange decisions. To economize on the number of required meetings, the chief dealer can be empowered to decide the amount of intervention up to a given threshold consistent with the central bank's exposure limits, including market and counterparty limits.

The central bank also needs to address the agency and governance problems that can arise with intervention. Dealers' objectives may differ from those of the policy authority and can lead to fraud and embezzlement. While these problems arise in any delegated trading, they may be particularly acute for central bank dealers because the information available to them is of high commercial value.

An adequate division of labor together with strong control systems can attenuate some of the agency and governance problems, as well as reduce some of the operational mistakes that may arise during trading. Trading activity should be separated from the confirmation and completion of the foreign exchange deals. At the "front office," central bank dealers constantly need to monitor market developments, contact market participants, and strike deals within their discretion. At the "back office," central bank staff confirm the terms of the contracts struck by dealers, helping to detecting operational mistakes as well as reducing the scope for fraud and embezzlement.

\section{IMF-SUPPORTED AdJUSTMENT PROGRAMS AND OFFICIAL INTERVENTION}

Most IMF-supported adjustment programs are designed and implemented on the heels of a currency crisis or a rapidly deteriorating external position-usually driven by an unsustainable exchange rate and monetary policy mix. By the time a member country approaches the Fund for financing, its international reserves are often precariously low. As a result, restraining domestic demand, restoring balance of payments viability, and strengthening international reserves are core elements of stabilization programs (Mussa and Savastano, 1999). Indeed, Fund credits to member countries in part aim to supplement gross international reserves, rebuild confidence in the local currency, and deter (further) speculative attacks.

Fund-supported programs often set a floor on net international reserves (NIR), which serves as a performance criterion (Polak, 1997). ${ }^{46}$ The accounting identities upon which programs

\footnotetext{
${ }^{46}$ According to the Monitoring of Fund Arrangements Reporting System, 84 percent of the
} 181 arrangements between 1993 and 1999 had performance criteria on reserves. 
are based ensure that the restoration of external viability yields a build up in reserves. ${ }^{47}$ To the extent that a program country fails to tighten macroeconomic policies, reverse the reserve losses of the past, and maintain the prescribed level of NIR (or achieve the prescribed build up), then the breach of NIR floor signals the need for a possible adjustment in policies or the program itself (Mussa and Savastano, 1999).

Improving external competitiveness--through both macroeconomic adjustment and structural reforms - is one of key objectives of many programs. To this end, exchange rate flexibility is often an important part of adjustment measures designed to achieve the targeted balance of payments improvement. Flexibility allows the exchange rate to adjust to external developments, which are usually difficult to predict, especially if the country is closely linked with international financial markets. To the extent that an exchange rate overvaluation was a contributor to external financial weaknesses, an exchange rate depreciation bolsters export competitiveness and serves as an expenditure-reducing and expenditure-switching device. ${ }^{48}$ Structural reforms complement macroeconomic adjustment policies and are critical to achieving and maintaining external competitiveness and to macroeconomic stability more generally. ${ }^{49}$

Fund-supported programs can have important implications for official intervention in the foreign exchange market for countries with flexible exchange rate regimes. First, in many programs, floors are set on net international reserves (NIR), which limit the capacity of the central bank to sell foreign exchange. In effect, Fund programs often advise the authorities to confine their interventions to smoothing exchange rate volatility. Second, the reserve accumulation envisaged under many Fund-supported programs--.through gradually rising NIR floors-creates asymmetry in exchange rate and intervention policies, by design. In particular, programs aim to limit interventions in defense of an exchange rate under downward pressure for a protracted period, especially if the exchange rate level is inconsistent with underlying macroeconomic policies. However, they are usually silent on or more tolerant of interventions to stem currency appreciation.

${ }^{47}$ For a more detailed discussion of the macroeconomic accounting framework underlying Fund-supported programs, see IMF (1987) and Polak (1997).

${ }^{48}$ Even though the exchange rate's role in restoring competitiveness remains a controversial topic, IMF surveillance and program missions pay close attention to real exchange rate trends.

${ }^{49}$ Structural reforms include trade liberalization, price liberalization, banking system restructuring, strengthening social safety nets, and reforms in the tax system, government spending, the labor market, prudential regulation and supervision, the foreign exchange market, and in other areas (Mussa and Savastano, 1999). 
The challenge for most program countries is thus to intervene to accumulate reserves, while minimizing the impact of intervention on the exchange rate. This can be achieved in several ways, depending on individual country circumstances, market conditions and the credibility of the central bank.

- Secret intervention. Like any other customer, the central bank intervenes in the market secretly, without disclosing, ex ante or ex post, its purpose or market presence. This strategy would be similar to those followed when the central bank intervenes on behalf of the government or for portfolio rebalancing purposes, where minimizing the price impact is also a primary consideration.

- $\quad$ Periodic and preannounced purchase. The central bank preannounces periodic foreign exchange purchase auctions. ${ }^{50}$ While this may minimize intervention's impact on the exchange rate, advance knowledge of the timing and amount of its foreign exchange purchases may allow market participants to take advantage of the central bank (e.g. by manipulating rates before the auctions). Moreover, purchases may coincide with moments of downward pressure, potentially adding to exchange rate volatility and risking positive feedback trading.

- $\quad$ Put option sales. Put option sales are another way to reduce intervention's impact on the exchange rate because the foreign exchange sale occurs at the initiative of market participants, whenever there is upward pressure on the currency. Moreover, the mechanism should limit the potential losses faced by the central bank (Box 1).

Interventions to calm disorderly markets and smooth exchange volatility should be rare and warrant particular scrutiny for program countries. Disorderly markets are difficult to detect and should not be used as "cover" for targeting a particular exchange rate level under a flexible exchange rate regime. Infrequent recourse to intervention for exchange rate purposes, moreover, enhances its effectiveness by maximizing the element of surprise. Monetary authorities thus should be rigorous in their analysis of market conditions and intelligence gathering and selective in their interventions.

Given that many countries with Fund-supported programs face weak credibility, intervention objectives should be stated publicly and be well understood by market participants. Provided that the underlying macroeconomic imbalances have been properly addressed, the authorities would have much to gain from increasing the transparency and accountability of their intervention objectives.

${ }^{50}$ Countries adopting Fund programs can follow the example of the European Central Bank, which has issued press releases stating its planned sale or purchase of foreign exchange when intervening for portfolio rebalancing purposes. The auction should be designed to avoid multiple currency practices subject to Fund jurisdiction. 


\section{Conclusion}

This paper attempts to offer guidance to central banks in developing countries on how to design and implement their interventions in foreign exchange markets. Its primary goal has been to devise solutions to the day-to-day operational issues faced by central banks in their interventions under flexible exchange rate regimes.

The main themes and best practices advocated in this paper are as follows:

- Intervention is not an independent policy tool. Its success is conditional upon the consistency of intervention objectives with macroeconomic policies. It is unlikely to be effective, particularly over the long term, when adverse exchange movements reflect persistent macroeconomic imbalances and deteriorating investor confidence in the currency. In particular, protracted one-sided interventions should be avoided.

- Intervention may be used, however, in conjunction with policies to redress macroeconomic imbalances. Intervention can complement efforts to place the macroeconomic policies on a sustainable path by resisting disruptive changes in the exchange rate, but only if there is a credible commitment to, and tangible progress on, macroeconomic adjustment.

- Central banks should be rigorous in their analysis of market conditions, judicious in their decisions to use scarce foreign exchange reserves, and parsimonious in their interventions. Exchange rate misalignments and disorderly markets are extremely difficult to detect. Therefore, interventions to smooth volatility and correct for misalignment should not be used as cover for targeting a particular exchange rate level under a flexible exchange rate regime. Infrequent recourse to intervention for exchange rate purposes, moreover, enhances its effectiveness by maximizing the element of surprise.

- Determining the timing and amount of intervention is a highly subjective exercise. The two depend heavily on the nature and permanence of economic shocks and exchange rate pressures, other observable market indicators, market intelligence, economic forecasts, and available reserves. Policy rules and economic models can provide guidance and "rules of thumb" for intervention, but usually have limited practical application and require a heavy dose of judgment. Hence, some degree of discretion is often necessary. Discretion also allows the central bank to accommodate market conditions and gives it room for tactical maneuver. Rules-based intervention policies may be appropriate under certain circumstances, including for accumulating reserves and supplying foreign exchange to the market.

- Intervention policies and objectives should be transparent and clearly specified. Transparency in intervention objectives can enhance the credibility of the central bank by holding it accountable for its record of policy implementation, even though the degree of transparency on the tactical implementation of intervention policies may 
vary with the specific objectives of intervention. Ensuring precision in intervention objectives is critical to its successful execution and to assessing its effectiveness ex post. Intervention objectives, moreover, should be reassessed constantly in light of the shocks faced by the economy, the macroeconomic policy mix, and available reserves.

- Central banks generally should refrain from funding intervention by borrowing, when net international reserves are low. Foreign currency debt-financed interventionthrough either on-balance-sheet or off-balance-sheet operations-creates risks that may not be justified by the uncertain and often limited effectiveness of intervention, particularly when reserves and credibility are low and market access is limited.

- Interventions should normally be executed in the most liquid markets where price discovery occurs. In particular, intervention for exchange rate purposes should normally occur in the spot market, where it is easier to find counterparties and where intervention directly affects the exchange rate. Intervention should also normally be conducted onshore and in the currency most widely traded to reduce costs and facilitate settlement, but may on occasion be conducted offshore to prevent destabilizing trading activity from affecting domestic markets.

The applicability of the proposed best practices, however, ultimately depends on countryspecific circumstances, including central bank credibility, the structure and depth of the foreign exchange market, and the macroeconomic and political environment. The proposed best practices are intended to provide guidance to central banks and stimulate further research. 


\section{References}

Bank for International Settlements, 1994, "Macroeconomic and Monetary Policy Issues Raised by the Growth of Derivatives Markets," (Basel: Bank of International Settlements).

Bartolini, Leonardo, 2002, "Foreign Exchange Swaps," New England Economic Review Second Quarter, p. 11

Beattie, Neil, and Jean-Francois Fillion, 1999, "An Intraday Analysis of the Effectiveness of Foreign Exchange Intervention," Bank of Canada Working Paper 99-4.

Bjorksten, Nils, and Anne-Marie Brook, 2002, "Exchange Rate Strategies for Small Open Developed Economies Such As New Zealand," Reserve Bank of New Zealand.

Boyer, Russell S., 1978, "Optimal Foreign Exchange Intervention," The Journal of Political Economy, Vol. 86 (December), pp. 1045-1055.

Bredin, Don, Stilianos Fountas, and Eithne Murphy, 2002, "An Empirical Analysis of ShortRun and Long-Run Irish Exports: Does Exchange Rate Volatility Matter?" Central Bank of Ireland Technical Paper 01/RT/02.

Breuer, P., 1999, "Central Bank Participation in Currency Options Markets," IMF Working Paper 99/140 (Washington: International Monetary Fund).

Buiter, W.,1979, “Optimal Foreign Exchange Intervention with Rational Expectations.” in Trade and Payments Adjustment under Flexible Exchange Rates, ed. by J. Martin and A. Smith (London: Macmillan).

Bussiere, Matthieu, and Christian Mulder, 1999, "External Vulnerability in Emerging Market Economies: How High Liquidity Can Offset Weak Fundamentals, and the Effects of Contagion," IMF Working Paper 99/88 (Washington: International Monetary Fund).

Calvo, Guillermo A., and Carmen Reinhart, 2002, "Fear of Floating," Quarterly Journal of Economics, 117, pp. 379-408.

Canales-Kriljenko, Jorge Iván, 2003a, "Foreign Exchange Intervention in Developing and Transition Economies: Results of a Survey," IMF Working Paper 03/95 (Washington; International Monetary Fund). ,2003b, "Foreign Exchange Market Organization in Developing and Transition Economies: Evidence from a Survey," IMF Working Paper, forthcoming (Washington: International Monetary Fund) 
, Roberto Guimarães, and Cem Karacadağ, 2003, “The Empirics of Foreign Exchange Intervention in Emerging Markets" IMF Working Paper, forthcoming (Washington: International Monetary Fund).

Carstens, Agustín G., and Alejandro M. Werner, 1999, "Mexico's Monetary Policy Framework Under A Floating Exchange," Documento de Investigación No. 9905 (May) (Ciudad de Mexico: Banco de Mexico)

Cheung, Yin-Wong, and Menzie Chinn, "Macroeconomic Implications of the Beliefs and Behavior of Foreign Exchange Traders," mimeo UCSC, 1999.

Chinn, Menzie, 1998, "Before the Fall: Were East Asian Currencies Overvalued?" Emerging Markets Review Vol. 1, revision of NBER Working Paper 6491, August.

2000, "Before the Fall: Were East Asian Currencies Overvalued?" Emerging Markets Review, Vol. 1 (September), pp. 101-126.

, and G. Meredith, 2001, "Testing Uncovered Interest Parity at Short and Long Horizons," revision of NBER Working Paper 6797.

Clavijo, Sergio, 2002, "Politica Monetaria y Cambiaria en Colombia: Progresos y Desafios," Borradores de economía No. 201 (Bogota: Banco de la Republica). Available at http://www banrep.gov.co/docum/ftp/borra201.pdf.

Domac, Ilker, and Alfonso Mendoza, 2003, "Is There Room for Forex Intervention under Inflation Targeting Framework? Evidence from Mexico and Turkey," mimeo.

Dominguez, Kathryn M., 2003, "The Market Microstructure of Central Bank Intervention," Journal of International Economics, 59, pp. 25-45. , and Jeffrey Frankel, 1993a, Does Foreign Exchange Intervention Work? (Washington: Institute for International Economics). , 1993b, "Does Foreign Exchange Intervention Matter? The Portfolio Effect" American Economic Review, 83, pp. 1356-69.

Enoch, Charles, 1998, "Transparency in Central Bank Operations in the Foreign Exchange Market," IMF Paper on Policy Analysis and Assessment 98/2 (Washington: International Monetary Fund).

European Central Bank, 2000, "The Single Monetary Policy in Stage Three. General Documentation on Eurosystem Monetary Policy Instruments and Procedures" (Frankfurt: European Central Bank) 
Evans, Martin D., and Richard Lyons, 2002, "Order Flow and Exchange Rate Dynamics," Journal of Political Economy, Vol. 110 (February).

2003, "Frequently Asked Questions about the Micro Approach to FX," memo electronically available at http://faculty.haas.berkeley.edu/lyons/

Fasano, Ugo, 2000, "Review of the Experience with Oil Stabilization and Savings Funds in Selected Countries," IMF Working Paper 00/112 (Washington: International Monetary Fund).

Federal Reserve Bank of New York, 2003, "Administration of Relationships with Foreign Exchange Counterparties," mimeo (February 13).

Financial Markets Association, 2002, "The Model Code: The International Code of Conduct and Practice for the Financial Markets," (October) (Paris: The Financial Markets Association). See (www.aciforex.com/mktpractice/model_code.htm).

Foreign Exchange Committee (FEC), 2003, "Management of Operational Risk in Foreign Exchange," (New York: Federal Reserve Bank of New York). See http:/www.newyorkfed.org/fxc/2003/fxc033103.pdf.

Galan Medina, M., J. Duclaud Gonzalez de Castillo, and A. Garcia Tames, 1997, "A Strategy for Accumulating Reserves through Options to Sell Dollars," unpublished manuscript, 1997. Available through the website of the Banco De Mexico, http//www.banxico org mx/siteBanxicoINGLES/bPoliticaMonetaria/FSpoliticaMone taria, html

Geraats, Petra M., 2001, "Why Adopt Transparency? The Publication of Central Bank. Forecasts," ECB Working Paper 41 (Frankfurt: European Central Bank).

Hinkle, Lawrence, and Peter Montiel, 1999, Exchange Rate Misalignment: Concepts and Measurement for Developing Countries (Washington: The World Bank).

Hooyman, Catharina J., 1994. "The Use of Foreign Exchange Swaps by Central Banks." IMF Staff Papers, 41, pp. 149-62 (Washington: International Monetary Fund).

Hull, John, 1997, Options, Futures, and Other Derivatives (Upper Saddle River, New Jersey: Prentice-Hall).

Hung, Juan, 1997, "Intervention strategies and exchange rate volatility: a noise trading perspective," Journal of International Money and Finance, 6, pp. 779-793.

International Monetary Fund, 1987, Theoretical Aspects of the Design of Fund-Supported Adjustment Programs, IMF Occasional Paper No. 55 (Washington: International Monetary Fund). 
International Monetary Fund, 1998, "Reserve Impact of Forward Foreign Exchange Market Intervention (Box 2.11)," International Capital Markets Report (Washington: International Monetary Fund).

International Monetary Fund, 2002, "Principles for the Guidance of Members' Exchange Rate Policies" in Selected Decisions and Selected Documents of the International Monetary Fund, Twenty-Sixth Issue, see http://www.imforg/external/pubs/ft/sd/index.asp?decision=5392-(77/63).

International Monetary Fund, 2002, Annual Report on Exchange Arrangements and Exchange Restrictions (Washington: International Monetary Fund).

Isard, Peter, Hamid Faruqee, G. R.Kincaid, and Martin J. Fetherston, 2001, "Methodology for Current Account and Exchange Rate Assessments," IMF Occasional Paper No. 209 (Washington: International Monetary Fund).

Ishii, Shogo, Inci Otker-Robe, and Li Cui, 2001, "Measures to Limit the Offshore Use of Currencies: Pros and Cons," IMF Working Paper 01/43 (Washington: International Monetary Fund).

Ito, Takatoshi, 2002, "Is Foreign Exchange Intervention Effective?: The Japanese Experiences in the 1990s," NBER Working Paper 8914 (Cambridge, Massachusetts: National Bureau of Economic Research).

Jones, Michael, 1984, "Optimal Foreign exchange intervention: Evidence from the Bretton Woods Era," The Review of Economics and Statistics, Vol. 66, pp. 242-55.

Jorion, Philippe, 1995, "Predicting Volatility in the Foreign Exchange Market", Journal of Finance, 50, 2, pp. 507-528.

Lall, Subir, 1997, "Speculative Attacks, Forward Market Intervention and the Classic Bear Squeeze," IMF Working Paper 97/164 (Washington: International Monetary Fund).

Lyons, Richard, 2001, The Microstructure Approach to Exchange Rates (Cambridge, Massachusetts: MIT Press).

Mandeng, Ousmene-Jacques, 2003, "Central Bank Foreign Exchange Market Intervention and Option Contract Specification: The Case of Colombia," IMF Working Paper 03/135 (Washington: International Monetary Fund).

Mark, N., 2001, International Macroeconomics and Finance: Theory and Econometric Methods (New York: Blackwell Publishers). 
Moreno, R., 1997, "Lessons from Thailand," Federal Reserve Bank of San Francisco Economic Letter, Number 97-33, November 7, 1997.

Mulder, Christian, and Roberto Perrelli, 2001, "Foreign Currency Credit Ratings for Emerging Market Economies," IMF Working Paper 01/191 (Washington: International Monetary Fund).

Murray, John, Mark Zelmer, and Des McManus, 1996, "The Effect of Intervention on Canadian Dollar Volatility," in Exchange Rates and Monetary Policy, Proceedings of conference held by the Bank of Canada.

Mussa, Michael, 1981, The Role of Official Intervention (New York: Group of Thirty).

Mussa, Michael, and Miguel A. Savastano, 1999, "The IMF Approach to Economic Stabilization," IMF Working Paper 99/104 (Washington: International Monetary Fund).

Neely, C., 2001, "The Practice of Central Bank Intervention: Looking Under the Hood," Federal Reserve Bank of St. Louis Review, 83, pp. 1-10.

Nordman, Tom, 1997, "Central Bank Interventions in the Foreign Exchange Market under Different Conditions and Exchange Arrangements," mimeo.

Obstfeld, Maurice, 1990, "The Effectiveness of Foreign Exchange Intervention: Recent Experience, 1985-1988" in Branson, W., Frenkel, J, and Goldstein, M. eds., International Policy Coordination and Exchange Rate Fluctuations (Chicago: University of Chicago Press).

Polak, J.J., 1997, "The IMF Monetary Model at Forty," IMF Working Paper 97/49 (Washington: International Monetary Fund).

Ramaswamy, Ramana, and Hossein Samiei, 2000, "The Yen-Dollar Rate-Have Interventions Mattered?" IMF Working Paper 00/95 (Washington: International Monetary Fund).

Reserve Bank of Australia, 2001. The Exchange Rate and the Reserve Bank's Role in the Foreign Exchange Market.

Reserve Bank of India, 2002, "Inclusion of Euro as an Additional Intervention Currency," Press Release No. 986/2001-2002 Dated 04.03.2002, based on Notification S.0.235(E) dated February 27, 2002, electronically available at http://www gujaratchamber.org/notifications-rbi1.htm.

Rogoff, Kenneth, 1996, "The Purchasing Power Parity Puzzle," Journal of Economic Literature 34, pp. 647-68. 
, 1999, "Perspectives on Exchange Rate Volatility," in International Capital Flows (Chicago: University of Chicago Press).

Roper, Don E., and Stephen J. Turnovsky, 1980, "Optimal Exchange Market Intervention in a Simple Stochastic Macro Model," Canadian Journal of Economics, Vol. 13, pp. 296-309.

Sarno, Lucio and Mark P. Taylor, 2001, "Official Intervention in the Foreign Exchange Market: Is It Effective, and If So, How Does It Work," Journal of Economic Literature, Vol. 34 (September), pp. 839-68. 2002, The Economics of Exchange Rates (Cambridge: Cambridge University Press).

South African Reserve Bank, 1998, "The South African Reserve Bank's Forward Foreign Exchange Book," February 27. See http://www.resbank.co.za/ibd/fwdcover.html.

Sveriges Riksbank, 1999, "Currency Market Primary Dealer Agreement," mimeo. ,2002, The Riskbank's Intervention in the Foreign Exchange Market-Preparations, Decision-Making, and Communication.

Tanner, E., 1998, "Deviation from Uncovered Interest Rate Parity: A Global Guide to Where the Action Is," IMF Working Paper 98/117 (Washington: International Monetary Fund).

Taylor, Mark P., 1991, "Intervention, Interest Rates. and Charts: Three Essays in International Finance," IMF Working Paper 91/106 (Washington: International Monetary Fund).

Turnovsky, S., and E. Grinols, 1996, "Optimal Government Finance Policy and Exchange Rate Management in a Stochastically Growing Economy," Journal of International Money and Finance, Vol. 15 (5), pp. 687-716.

Werner, Alejandro, 1997, "El Efecto Sobre El Tipo De Cambio Y Las Tasas De Interes De Las Intervenciones En El Mercado Cambiario Y Del Proceso De Esterilizacion" Banco de Mexico Documento de Investigación No. 970.

Werner, A and A. Milo, 1998, “Acumulación de Reservas Internacionales a través de la venta de opciones: el caso de México," Documento de Investigación No. 9801, Banco de México.

Zapatero, Fernando, and Luis F. Reverter, 2003, "Exchange Rate Intervention with Options," Journal of International Money and Finance, Vol. 22, pp. 289-306. 